\title{
THE POTENTIAL OF FOREST BUFFER TO PREVENT STREAM FROM WATER POLLUTANTS: A CASE STUDY IN GROJOKAN SEWU SUB-WATERSHED, KARANGANYAR DISTRICT, CENTRAL JAVA
}

\author{
Nining Wahyuningrum ${ }^{1}$ and Irfan Budi Pramono ${ }^{1}$ \\ Received : 11 February 2013, Accepted : 12 September 2013
}

\begin{abstract}
Population growth leads to water scarcity in terms of both quality and quantity. Agricultural and urban watersheds potentially produce more pollutants than forested area. It is considered that forested area has potential in storing and protecting water supply in such a way that water distribution and quality can be guaranteed. The objective of the study was to determine the relationship between the percentages of forested area in a watershed with the water quality. The study was conducted in 2010 in Grojokan Sewu Sub-watershed, Karanganyar District, Central Java. Using GIS (Geographic Information System), this sub-watershed was divided into four sub-sub-watersheds with different percentages of forested areas. Water samples were collected in each sub-sub-watershed to find out the relationship between the forested area and the total dissolved solids, turbidity, sodium, nitrite, nitrate, sulfate and organic matters. The statistical analysis indicates relationships in quadratic form between sodium, nitrite, TDS, sulfate and organic matters with the percentage of forested area $\left(R^{2}=0.99\right.$, $R^{2}=0.99, R^{2}=0.98, R^{2}=0.95$ and $R^{2}=0.77$, respectively). The relationships are different from those of turbidity and nitrate that have low $R^{2}\left(R^{2}=0.28\right.$ and $\left.R^{2}=0.36\right)$ values. It implies that the forested area is capable to reduce sodium, nitrite, TDS, sulfate and organic matters, and thus water pollutants can be reduced by forest formation as it can filter water through retention of sediments and nutrients.
\end{abstract}

Keywords: Forest, water quality, watershed, land use

\section{INTRODUCTION}

Demand for water is rising rapidly in line with world's population growth. Water scarcity for drinking water as well as for agriculture is increasing. On the other hand ground water is being depleted as ecosystems are becoming polluted and degraded (Rosegrant et al., 2002). The water use is related to the consumption of the people. The water consumption of a country is defined as the volume of water needed for the production of the goods and the services consumed by the inhabitants of the country. USA appears to have an average water consumption of $2480 \mathrm{~m}^{3} / \mathrm{cap} / \mathrm{yr}$, while China has $700 \mathrm{~m}^{3} / \mathrm{cap} / \mathrm{yr}$. The global average water consumption is

Forestry Institute on Watershed Management, Jl. A. Yani Pabelan, Kartasura, PO Box 295, Surakarta

Corresponding Author: nining0709@yahoo.com
$1240 \mathrm{~m}^{3} / \mathrm{cap} / \mathrm{yr}$ (Hoekstra and Chapagain, 2007).

A wide range of construction and development activities can adversely affect the world's water supplies in terms of both quality and quantity. These conditions are also affected by land use formations. It is widely known that watershed hydrology depends on many factors, including land use, climate, and soil conditions. (Tong, 2002) Agricultural and urban watersheds potentially produce more pollutants than forested areas (Lenat and Crawford, 1994; Dauer et al., 2000; Fisher et al., 2000; Wang, 2001). It maybe the result of high concentration of fertilizers (Mattikalli and Richards, 1996) and municipal wastes (Fisher et al., 2000). Moreover, conversion of forested lands to agriculture and/or urban/ residential areas has been associated with declines in stream and lake water quality (Houlahan and Findlay, 2004). Therefore, forest is expected to be effective in maintaining water quality by reducing any 
pollutant into the river. By intercepting rain, a forest canopy reduces the impact of heavy rainfall on the forest floor and decreases soil disturbance. Leaves and natural debris on the forest floor may slow down the rate of water runoff and trap soil washing away from surrounding fields. Consequently, it reduces soil loss which potentially brings nutrient to the stream (Zisheng et al., 2011; Foltz, 2012).

Forest condition that manages to regulate water is the forest which has multilayers, such as natural forest (Tíscar and Linares, 2011) or agroforestry system (Suryanto and Putra, 2012). Natural forest which consists of trees at different stages of growth, such as seedlings, saplings, poles and mature trees creates canopy layers (Tíscar and Linares, 2011). This multilayer can also be found in agroforestry in which trees or shrubs are grown in association with agricultural crops (Suryanto and Putra, 2012). Based on that, characteristic of forested area acts as water filter and thus protects soil from erosion and surface run off (Wentai et al., 2011; Singh and Mishra, 2012), as well as supplies ground water discharge which provides oxygen to the stream (Núñez et al., 2006). Hairiah et al. (2012) reported that forest conversion to coffee-based agroforestry initially led to a decrease in the rate of litter fall and the accumulated litter layer covering the soil, replenishment of soil organic matter (SOM), and likely related to a reduction in soil macro porosity. On sloping land, a reduction of macro porosity and soil cover will increase overland flow and erosion (Hairiah et al., 2012). It indicates that the type of trees used as shade trees to the coffee can influence directly the physical conditions of the soil through their rooting pattern. A combination of trees with slowly decomposing litter, that help to protect the soil surface, and trees with deep root systems that directly create macro porosity is probably the best for securing soil conditions that meet the requirements of low surface runoff and erosion rates.

Based on the important effect of forested area on water quality, the study was aimed to determine the relationship between land use type composition (the percentage of forestcover) and water quality parameters, i.e. total dissolved solids (TDS), sodium $(\mathrm{Na})$, sulfate $\left(\mathrm{SO}_{4}\right)$, nitrite $\left(\mathrm{NO}_{2}-\mathrm{N}\right)$, nitrate $\left(\mathrm{NO}_{3}-\mathrm{N}\right)$ and organic matters in a watershed. To achieve the goal of the study, observation of water quality was conducted in four sub-watersheds which have different percentages of forested areas.

\section{MATERIAL AND METHOD}

\section{A. Location}

This research has been conducted in Grojokan Sewu Sub-watershed in Karanganyar District, Central Java. Geographically, which is located between $7^{\circ} 41^{\prime} 24.10^{\prime \prime}-7^{\circ} 37^{\prime} 32.48^{\prime \prime} \mathrm{S}$ and $111^{\circ} 07^{\prime} 27.07^{\prime \prime}-111^{\circ} 07^{\prime} 19.01^{\prime \prime E}$. Grojokan Sewu Sub-watershed was divided into four sub-subwatersheds: Grojokan Sewu, Blumbang, Gondosuli 1 and Gondosuli 2.

Grojokan Sewu Sub-watershed is dominated by undulating topography. This area was selected because there are extensive agricultural activities on steep slopes using intensive fertilizer (Prasetyo, 2013) which may lead to erosion and water pollution.

\section{B. Land cover classification}

Land cover map was generated from QuickBird image of September 29, 2006 which was downloaded from Google Earth in 2010. ArcMap 9.3 was used in image processing, such as geo referencing and digitizing. Geo referencing process utilized the coordinate system of WGS 84 based on images coordinates of Google Earth. On-screen digitizing was done by delineating similar patterns seen in the image, such as color and texture of the objects. Land cover types were divided into four types, i.e. vegetable garden, settlement, forest and shrub.

Ground checking survey was conducted in the same year as the image downloading. Survey was based on land cover map by matching the present type in the field with the map. To determine forest density, tree measurement was conducted to obtain parameters such as tree species, diameter at breast height $(\mathrm{DBH})$, tree height and number of trees in the $30 \mathrm{~m} \times 30 \mathrm{~m}$ sample plots (sample intensity was approximately 10\%). These plots were considered as training samples used to complete the image classification. 
Finally, land covers were classified into six classes such as vegetable crops, settlement, sparse plantation forest, moderately dense plantation forest, dense natural forest and shrubs. Cover story and under story were also analyzed in order to find out their effect on water filtering.

\section{Water sample analysis}

Water samples were collected in 2009 during the rainy season from each sub-subwatershed with different percentages of forested area. The samples (4 samples) were taken simultaneously. Each sample consisted of $1500 \mathrm{ml}$ water and it was analyzed in the Indonesian Ministry of Health's Laboratory, Yogyakarta. Parameters analyzed were turbidity, TDS, natrium, sulfate, nitrite, nitrate and organic matters. The standard methods used were SNI 06-6989.25-2005; SNI 06-6989.1-200; APHA2012, Section 3500-Na; SNI 6989.20-2009; SNI 06-6989.9-2004; APHA 2012, Section 4500- $\mathrm{NO}_{3}$ and SNI 066989.222004, respectively. Regression method was used to develop the relationship between forested area and each water quality parameter.

\section{RESULT AND DISCUSSION}

\section{Land cover types}

Based on image analysis there were six land cover classes in the study area, i.e. vegetable crops, settlement, sparse plantation forest, moderately dense plantation forest, dense natural forest and shrubs. The distribution of land cover types is presented in Figure 1.

Settlements are generally situated in flat areas, while vegetable gardens, forests and shrubs are found in areas with steeper slopes, in areas with slope of more than $45 \%$. Based on the map, Grojokan Sewu Sub-watershed is dominantly covered by forests $(55 \%)$ (Table 1$)$. Table 1 shows the percentage of forested area in each sub-watershed, namely Gondosuli 2 (88\%), Gondosuli 1 (72\%), Blumbang (64\%) and Grojokan Sewu (55\%). The forest cover type was divided into three classes based on density levels, i.e. (1) sparse plantation forest, (2) moderately dense plantation forest, and (3) dense natural forest. The forest density is influenced by the type of plant, tree density per ha, canopy closure, understory plants and diameter (Table 2).

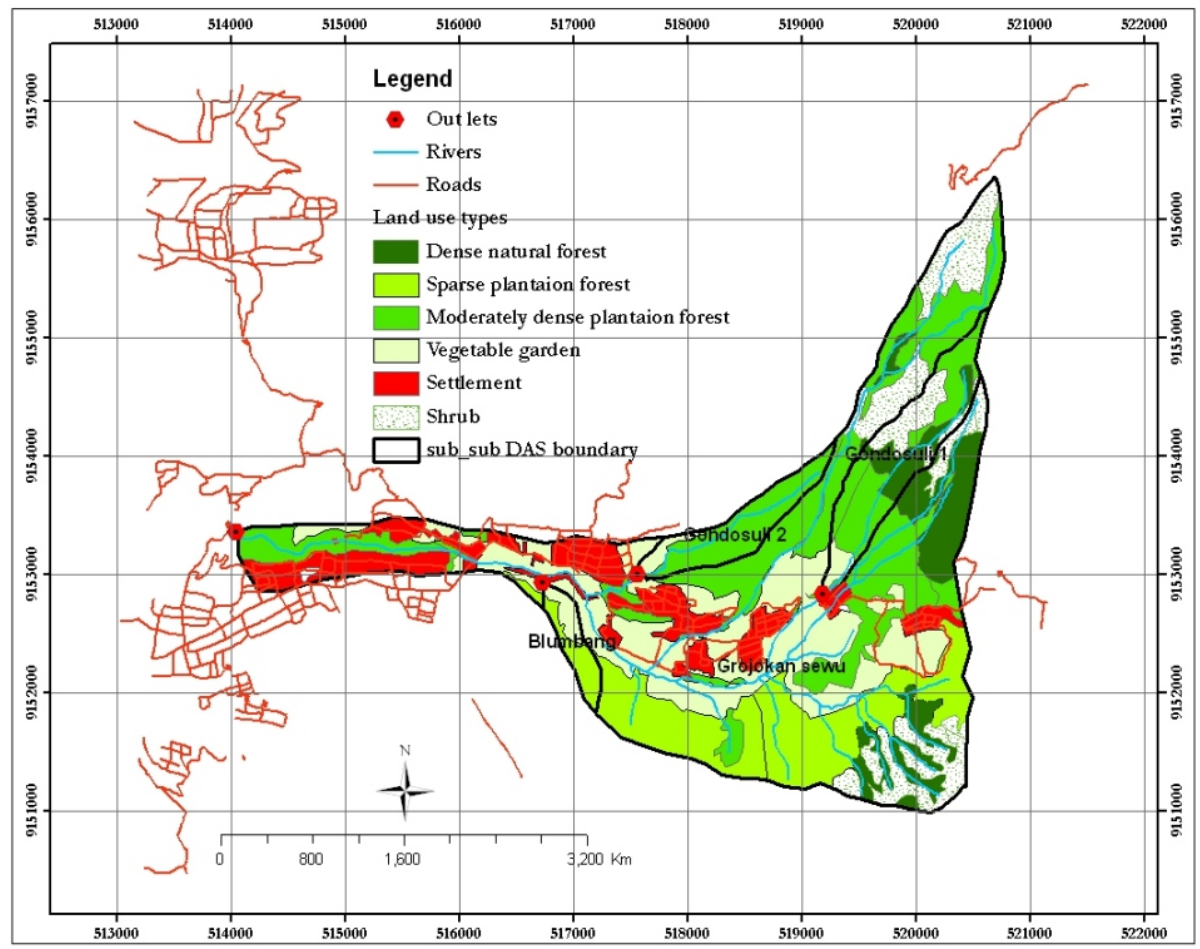

Figure 1. Land cover map of Grojokan Sewu Sub-watershed 
Table 1. Distribution of land cover types in each sub-watershed

\begin{tabular}{|c|c|c|c|c|c|c|c|c|}
\hline \multirow{3}{*}{$\begin{array}{l}\text { Land cover } \\
\text { types }\end{array}$} & \multicolumn{8}{|c|}{ Sub-watersheds } \\
\hline & \multicolumn{2}{|c|}{ Blumbang } & \multicolumn{2}{|c|}{ Gondosuli 1} & \multicolumn{2}{|c|}{ Gondosuli 2} & \multicolumn{2}{|c|}{ Grojokan Sewu } \\
\hline & $\begin{array}{l}\text { Area } \\
\text { (ha) }\end{array}$ & $\%$ & Area (ha) & $\%$ & $\begin{array}{l}\text { Area } \\
\text { (ha) }\end{array}$ & $\%$ & $\begin{array}{l}\text { Area } \\
\text { (ha) }\end{array}$ & $\%$ \\
\hline $\begin{array}{l}\text { Vegetable } \\
\text { garden }\end{array}$ & 7.99 & 36.27 & 5.80 & 5.91 & 6.23 & 11.95 & 249.37 & 22.05 \\
\hline Settlement & - & & 0.53 & 0.54 & - & - & 125.50 & 11.10 \\
\hline $\begin{array}{l}\text { Sparse } \\
\text { plantation } \\
\text { forest }\end{array}$ & 14.04 & 63.73 & - & - & - & - & 182.88 & 16.17 \\
\hline $\begin{array}{l}\text { Moderately } \\
\text { dense } \\
\text { plantation } \\
\text { forest }\end{array}$ & - & - & 49.57 & 50.47 & 45.91 & 88.05 & 334.15 & 29.55 \\
\hline $\begin{array}{l}\text { Dense natural } \\
\text { forest }\end{array}$ & - & - & 20.77 & 21.15 & - & - & 102.70 & 9.08 \\
\hline Shrubs & - & - & 21.53 & 21.93 & - & - & 136.17 & 12.04 \\
\hline Total & 2.03 & 100.0 & 98.21 & 100.0 & 52.14 & 100.0 & 1130.77 & 100.0 \\
\hline
\end{tabular}

Table 2. Forest condition and density of Grojokan Sewu Sub-watershed

\begin{tabular}{|c|c|c|c|c|c|c|c|}
\hline \multirow[b]{2}{*}{$\begin{array}{l}\text { Land cover } \\
\text { type }\end{array}$} & \multirow[b]{2}{*}{ Species } & \multicolumn{3}{|c|}{ Density of } & \multirow{2}{*}{$\begin{array}{l}\text { Average } \\
\text { DBH }(\mathrm{cm})\end{array}$} & \multicolumn{2}{|c|}{ Area } \\
\hline & & $\begin{array}{c}\text { Forest } \\
\text { canopy } \\
(\%)\end{array}$ & $\begin{array}{l}\text { Understory } \\
\text { plant (shrubs) }\end{array}$ & $\begin{array}{l}\text { Trees } \\
\text { per ha }\end{array}$ & & (ha) & $(\%)$ \\
\hline $\begin{array}{l}\text { Sparse } \\
\text { plantation } \\
\text { forest }\end{array}$ & $\begin{array}{l}\text { Pinus merkusii, } \\
\text { Acacia decurent }\end{array}$ & 26.7 & $\begin{array}{l}\text { Sparse- } \\
\text { moderate }\end{array}$ & 675.0 & 9.0 & 182.88 & 16.17 \\
\hline $\begin{array}{l}\text { Moderately } \\
\text { dense } \\
\text { plantation } \\
\text { forest }\end{array}$ & $\begin{array}{l}\text { Pinus merkusii } \\
\text { Jungh, Acacia } \\
\text { decurent }\end{array}$ & 61.0 & $\begin{array}{l}\text { Moderate- } \\
\text { dense }\end{array}$ & 835.0 & 15.3 & 334.15 & 29.55 \\
\hline $\begin{array}{l}\text { Dense natural } \\
\text { forest }\end{array}$ & Mixed species & 86.7 & $\begin{array}{l}\text { Uniformly } \\
\text { Dense }\end{array}$ & 1033.3 & - & 102.70 & 9.08 \\
\hline
\end{tabular}

Natural forests are densely populated by mixed species of trees and shrubs. Species of shrubs found in the area were Gleichenia linearis, Eupatorium odoratum, Nephrolelepis falcata, Mimosa pudica, Centotheca lappacea, Echinocloa colonum, Aristolochia tagala, Dicranopteris linearis, Cyperus rotundus, and Imperata cylindrica.

\section{Water quality}

The statistical analysis indicates a relationship in quadratic form between Sodium, Nitrite, TDS, Sulfate and organic matters with the percentage of forested area whereas this relationship is not found between turbidity and nitrate and the percentage of forested area (Table 3).

These relationships between the forested area with TDS, turbidity and other chemical materials are graphed in Figure 2 and Figure 3.

The relationship between TDS and other chemical contents with the percentage of forested area are in line with the fact that primary sources for TDS and other chemical contents in waters are agricultural and residential runoffs, leaching of contaminated soil and point source water pollution discharge from industrial or sewage treatment plants. Runoff may contain chemical materials such as sulfate, nitrites, nitrates, sodium, 
and organic matters. In agriculture (non-forested) area the application of inorganic fertilizers tends to deliver high concentration of nitrates. In addition the well-drained area contained the highest concentration of nitrates(Hamilton and Helsel, 1995; Coulter et al., 2004). Moreover, water from forested catchments has lower nitrates content compared to those from farmland, and residential areas(Ngoye and Machiwa, 2004).

The relationship between turbidity and forested area is similar to the research found by Coulter et al. (2004). They concluded that turbidity is generally higher in the urban and mixed watersheds. Intensive agriculture in the study area by applying intensive tillage and sewage from settlement might be the source of pollutants. These pollutants are delivered to the rivers through runoff and erosion. Surface-runoff, stream flow and overland flow also increase the turbidity level of the water. Turbidity will further influence the other water quality parameters such as TDS. Tillage erosivity increases exponentially with tillage depth. Therefore reducing tillage depth can be considered as an effective soil conservation strategy (Oost et al., 2006).

The forested area reduces pollutants by taking up nutrients and, especially in saturated riparian areas, creating conditions (anaerobic soil conditions and energy source of organic material) for de-nitrification (reduction of nitrite and nitrate to $\mathrm{N}_{2}$ gas). Moreover, higher nitrate-N concentrations were found in streams with adjacent forest cover (Ice and Binkley, 2003; Messer et al., 2012). Forested area e.g. riparian forest has also a function of maintaining water quality by protecting land from runoff and erosion. Riparian forest can reduce the carbon export to water bodies and forest buffers are effective in protecting water quality and aquatic life, particularly when it is wider than $40 \mathrm{~m}$ (Gundersen et al., 2010). Furthermore, riparian forests are highly valued for maintaining water quality through the retention of sediments and nutrients. In addition increases in land development will likely lead to greater erosion and sediment deposition in these areas (Jolley et al.,

Table 3. Relationship of water quality parameters with the percentage of forested area

\begin{tabular}{|c|c|c|c|c|c|}
\hline Parameters & Equations & $R^{2}$ & Adj. $R^{2}$ & SEE & Sig. \\
\hline Sodium $(\mathrm{mg} / \mathrm{l})$ & $Y=0.0317 X^{2}-4.7236 X+186.98$ & 0.99 & 0.93 & 0.54 & $0.065^{* *}$ \\
\hline $\mathrm{NO}_{2}-\mathrm{N}(\mathrm{mg} / \mathrm{l})$ & $Y=2 \mathrm{E}-06 X^{2}-0.0004 X+0.0161$ & 1 & 1 & 0 & $0^{*}$ \\
\hline TDS (mg/l) & $Y=0.1623 X^{2}-24.898 X+1014.3$ & 0.98 & 0.93 & 8.62 & $0.15^{\mathrm{ns}}$ \\
\hline $\mathrm{SO}_{4}(\mathrm{mg} / \mathrm{l})$ & $Y=0.0472 X^{2}-6.875 X+250.59$ & 0.95 & 0.85 & 2.68 & $0.22^{\mathrm{ns}}$ \\
\hline Organic Matters (mg/l) & $Y=-0.0078 X^{2}+1.0495 X-28.767$ & 0.77 & 0.32 & 1.39 & $0.47^{\mathrm{ns}}$ \\
\hline Turbidity (NTU) & $Y=14.435 \mathrm{e}^{-0.022 X}$ & 0.28 & -0.77 & 0.61 & $0.46^{\mathrm{ns}}$ \\
\hline $\mathrm{NO}_{3}-\mathrm{N}(\mathrm{mg} / \mathrm{l})$ & $Y=5.6564 \mathrm{e}^{-0.065 X}$ & 0.36 & -0.97 & 1.5 & $0.40^{\mathrm{ns}}$ \\
\hline & $\begin{array}{l}\text { Remarks: } Y=\text { water quality } \\
X=\text { percentage of forested area }(\%)\end{array}$ & \multicolumn{4}{|c|}{$\begin{array}{l}\mathrm{ns}=\text { not significant } \\
* *=\text { significant at } 0.1 \\
*=\text { significant at } 0.05\end{array}$} \\
\hline
\end{tabular}

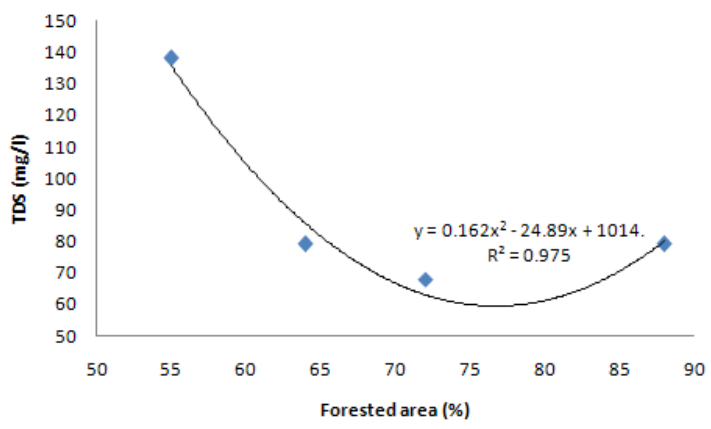

(a)

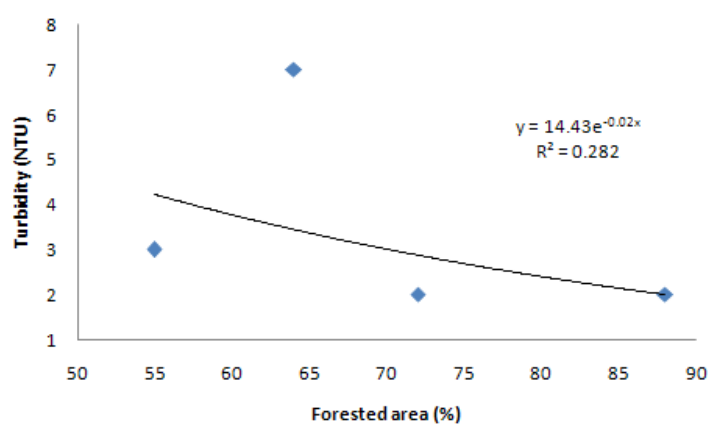

(b)

Figure 2. The relationship between forested area with TDS and turbidity of Grojokan Sewu Subwatershed 


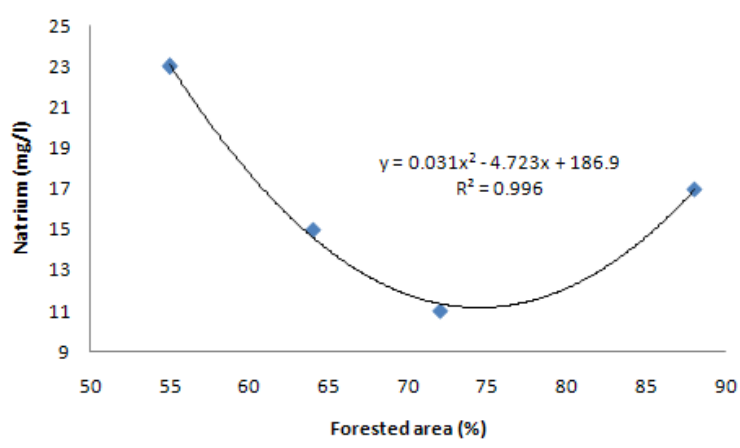

(a)

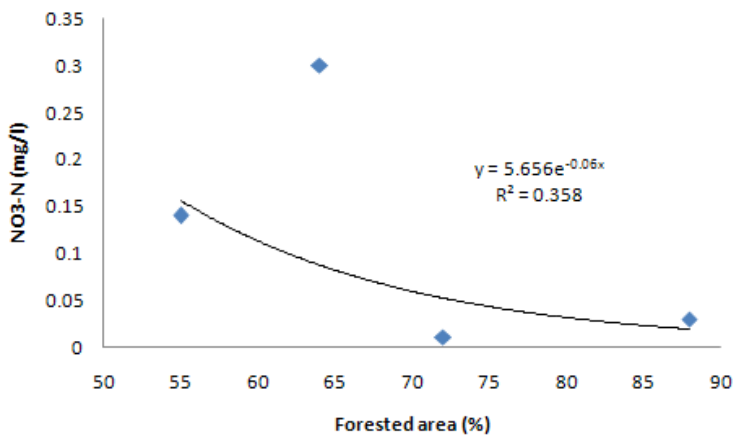

(c)

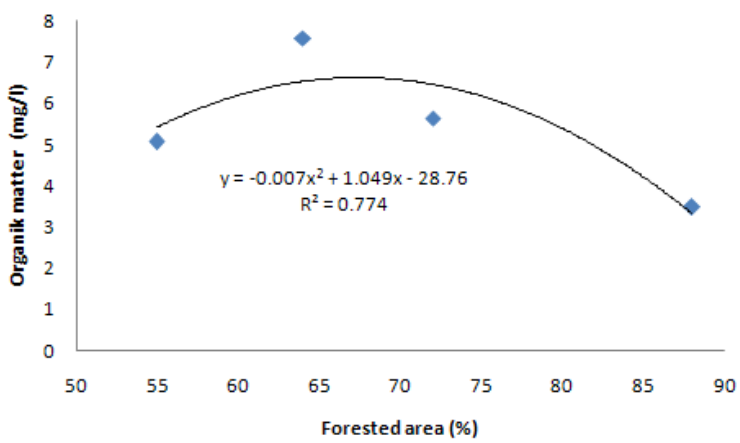

(d)

2010).

Fragment size, or length and width of riparian forest and vegetation type, and fragment location in the catchment may have critical roles in enabling forest fragments to reduce the negative impacts of agriculture. The characteristics of fragments have important consequences for stream remediation. Moreover, small forest fragments can mitigate upstream agricultural effects on water quality (Harding et al., 2006). Therefore, forestry practices e.g. urban forest can be functioned as a buffer region in urbanizing watershed to protect and to improve water quality (Matteo et al., 2006; Vyas et al., 2012). The urban forest cover substantially is a benefit to water quality and water quantity at a watershed scale. It was observed that previous cover reduced the

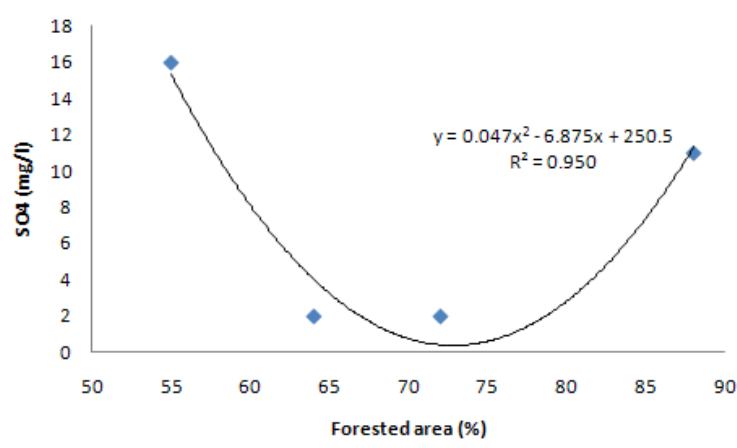

(b)

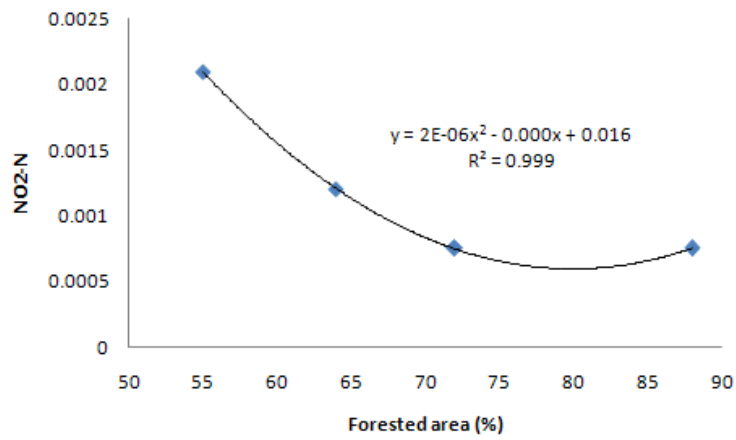

(d)

Figure 3. Relationship of chemical materials such as natrium (a), SO4 (b), NO3-N (c) NO2-N (d) and organic matter (d) with the percentage of forested area

problem of non point source pollution from sediment and nutrient entering into urban watershed systems. Combining riparian and roadside buffers for urban forestry can provide substantial improvements in water quality. In addition, runoff decreased under these spatial policies, thus mitigating storm water problems. Nutrient loss is reduced through tree uptake and reduction in sediment loading (Matteo et al., 2006).

Existence of forest increases precipitation and water availability. Progressive deforestation, land conversion from forest to agriculture and urbanization has potentially negative consequences on global precipitation. Therefore, forest ecosystems are fundamental for providing and maintaining freshwater resources, maintaining human health, agricultural production and economic activity 
(Ellison et al., 2011).

On the other hand, forest may act also as the source of chemical elements resulting from the decomposition of litter (Congyan et al., 2012) such as lignin, Nitrate, Carbon and Phosphorus (Mitchell et al., 2011; Moore et al., 2011). Congyan et al. (2012) concluded that high temperature and intensive precipitation may lead to an accelerated decomposition of litter of conifer and also of broad leave forest in the tropics. Both the litter and forest floor material favor decomposition and nutrient mineralization processes (Laganiere et al., 2010). Moreover, microbial community composition also plays an important role in decomposition (Powers et al., 2009; Bray et al., 2012).

Based on the fact that water pollutants can be reduced by forest formation, it is recommended to build forest buffer strips for trapping non pointsource pollutants and protecting surface water quality (Endreny, 2002). In this regard there are three aspects that should be considered: (1)the likelihood for excess pollutant on a watershed site is a function of the land cover type or use, (2)the likelihood for run off to leave a watershed site is a function of the size of the upslope contributing area and the slope, and (3) the likelihood for polluted runoff to enter a surface water body is a function of the opportunities for pollution filtering within the runoff dispersal area.

\section{CONCLUSION}

The percentage of forested area has relationships with Sodium, Nitrite, TDS, Sulfate and organic matters in quadratic forms. It implies that forested area may reduce Sodium, Nitrite, TDS, Sulfate and organic matters, and water pollutants can be reduced by forest formation as it can filter water through retention of sediments and nutrients.

\section{REFERENCES}

Bray, S. R., Kitajima, K., \& Mack, M. C. (2012). Temporal dynamics of microbial communities on decomposing leaf litter of 10 plant species in relation to decomposition rate. Soil Biology \& Biochemistry, 49, 30-37.
Congyan, W., Guomin, H., \& Yong, J. (2012). Insight into the temperature sensitivity of forest litter decomposition and soil enzymes in ubtropical forest in China. Journal of Plant Ecology, 5, 279286.

Coulter, C. B., Kolka, R. K., \& Thompson, J. A. (2004). Water quality in agricultural, urban and mixed land use watersheds. JAWR A Journal of the American Water Resources Association, 40, 15931601.

Dauer, D. M., Ranasinghe, J. A., \& Weisberg, S. B. (2000). Relationships between benthic community condition, waterquality, sediment quality, nutrient loads, and land use patterns in Chesapeake Bay. Estuaries, 80-96, 80-96.

Ellison, D., Futter, M. N., \& Bishop, K. (2011). Review on the forest coverwater yield debate: from demand to supply-side thinking. Global Change Biology, 18, 806-820.

Endreny, T. A. (2002). Mapping the water quality benefits: Forest buffer strips. Journal of Forestry, 100,35-40.

Fisher, D. S., Steiner, J. L., \& Endale, D. M. (2000). The relationship of land use practices to surface water quality in the Upper Oconee Watershed of Georgia. Forest Ecology and Management, 128, 38-48.

Foltz, R. B. (2012). A comparison of three erosion control mulches on decommissioned forest road corridors in the northern Rocky Mountains, United States. Journal of Soil \& Water Conservation, 67, 536-544.

Gundersen, P., Laure'n, A., \& Fine'r, L. (2010). Environmental services provided from Riparian Forests in the Nordic Countries. AMBIO, 39, 555-566.

Hairiah, K., Suprayogo, D., \& Widianto, D. (2012). Alih guna lahan butan menjadi laban agroforetri berbasis kopi: Ketebalan seresah, populasi cacing anah dan makroporositas tanah.

Hamilton, P. A., \& Helsel, D. R. (1995). Effects of Agriculture on Ground-Water Quality in Five Regions of the United States. Ground Water, 33, 217-226.

Harding, J. S., Claassen, K., \& Evers, N. (2006). Can forest fragments reset physical and water quality conditions in agricutural catchments and act as refugia for forest stream invertebrates? Hydrobiologia, 568, 391-402.

Hoekstra, A. Y., \& Chapagain, A. K. (2007). Water footprints of nations: Water use by people as a function of their consumption pattern. Water 
Resources Management, 21, 35-48.

Houlahan, J. E., \& Findlay, C. S. (2004). Estimating the 'critical' distance at which adjacent land use degrades wetland water and sediment quality. Landscape Ecology, 19, 677-690.

Ice, G., \& Binkley, D. (2003). Forest streamwater concentration of nitrogen and phosphorus: a comparison with EPA's proposed water quality criteria. Journal of Forestry, 101(1), 21-28.

Jolley, R. L., Lockaby, B. G., \& Cavalcanti, G. G. (2010). Changes in riparian forest composition along a sedimentation rate gradient. Plant Ecol, 210, 317-330.

Laganiere, J., Pare, D. and Bradley, R.L. (2010). How does a tree species influence litter decomposition? Separating the relative contribution of litter quality, litter mixing, and forest floor conditions. Can. J. For. Res. 40: 465475.

Lenat, D. R., \& Crawford, J. K. (1994). Effects of and use on water quality and aquatic biota of three North Carolina Piedmont streams. Hydrobiologia, 294, 185-199.

Matteo, M., Randhir, T., \& Bloniarz, D. (2006). Watershed-scale impacts of forest buffers on water quality and runoff in urbanizing environment. Joumal of Water Resources Planning and Management, 132, 144-152.

Mattikalli, N. M., \& Richards, K. A. (1996). Estimation of surface water quality changes in response to land use change: Application of the export coefficient model using remote sensing and geographical information system. Journal of EnvironmentalManagement, 48, 263-282.

Messer, T. L., Burchell, M. R., Grabow, G. L., \& Osmond, D. L. (2012). Groundwater nitrate reductions within upstream and down stream sections of a riparian buffer. Ecological Engineering, 47, 297-307.

Mitchell, J. D., Lockaby, B. G., \& Brantley, E. F. (2011). Influence of Chinese privet (Ligustrumsinense) on decomposition and nutrient availability in Riparian Forest,. Invasive Plant Science and Management, 4, 437-447.

Moore, T. R., Trofymow, J. A., Prescott, C. E., \& Titus, B. D. (2011). Nature and nurture in the dynamics of $\mathrm{C}, \mathrm{N}$ and $\mathrm{P}$ during litter decomposition in Canadian forests. Plant Soil, 339, 163-175.

Ngoye, E., \& Machiwa, J. F. (2004). The influence of land-use patterns in the Ruvu river watershed on water quality in the river system. Physics and
Chemistry of the Earth, Parts $A / B / C, 29,1161$ 1166.

Núñez, D., Nahuelhual, L., \& Oyarzún, C. (2006). Forests and water: The value of native temperate forests in supplying water for human consumption. Ecological Economics, 58, 606-616.

Oost, K. V., Govers, G., Alba, S. D., \& Quine, T. A. (2006). Tillage erosion: a review of controlling factors and implications for soil quality. Progress in Physical Geography, 30, 443-466.

Powers, J. S., Montgomery, R. A., \& Adair, E. C. (2009). Decomposition in tropical forests: a pantropical study of the effects of litter type, litter placement and mesofaunal exclusion across a precipitation gradient. Journal of Ecology, 97, 801-811.

Prasetyo, W. (2013). Demi bawang, ketersediaan pupuk dijamin. Retrieved September 13, 2013, from http://m.suaramerdeka.com/index.php/read /cetak/2013/06/28/229203

Rosegrant, M. W., Cai, X., \& Cline, S. A. (2002). Global water Outlook to 2025; Averting an impending crisis. A 2020 vision for food, agriculture and environment initiative. Colombo: International Water Management Institute.

Singh, S., \& Mishra, A. (2012). Spatiotemporal analysis of the effects of forest covers on water yield in the Western Ghats of peninsular India. Journal of Hydrology, 446-447, 24-34.

Suryanto, P., \& Putra, E. T. S.(2012). Traditional enrichment planting in agroforestry marginal land Gunung Kidul, Java, Indonesia. Journal of Sustainable Development, 5(2), 77-87.

Tíscar, P. A., \& Linares, J. C. (2011). Structure and regeneration patterns of Pinus nigra subsp. salzmannii natural forests: A basic knowledge for adaptive management in a changing climate. Forests, 2, 1013-1030.

Tong, S. T. Y., \& Chen, W. (2002). Modeling the relationship between land use and surface water quality. Journal of Environmental Management, 66, 377-393.

Vyas, V., Kumar, A., Wani, S. G., \& Parashar, V. (2012). Status of Riparian Buffer Zone and floodplain areas of River Narmada, India. International Journal of Environmental Sciences, 3(1), 659.

Wang, X. (2001). Integrating water-quality management and land-use planning in a watershed context. Journal of Environmental Management, 61, 25-36.

Wentai, Z., Dongsheng, Y., \& Xuezheng, Y. (2011). The suitability of using leaf area index to 
quantify soil loss under vegetation cover. J. Mt. Sci, 8, 564-570.

Zisheng, Y., Huali, H., \& Qiaogui, Z. (2011). Soil erosion control degree of the project of converting farmland to forest in mountain areas at China's Southwest border: A case study in Mangshi, Yunnan Province. J. Mt. Sci, 8, 845854. 